\title{
Degradation of the low-calorie sugar substitute 5-ketofructose by different bacteria
}

\author{
Jacqueline Schiessl ${ }^{1}$ • Konrad Kosciow ${ }^{1} \cdot$ Laura S. Garschagen $^{1}$ • Juliane J. Hoffmann ${ }^{1}$ • Julia Heymuth ${ }^{1}$. \\ Thomas Franke ${ }^{1} \cdot$ Uwe Deppenmeier $^{1}$
}

Received: 24 September 2020 / Revised: 28 January 2021 / Accepted: 3 February 2021 / Published online: 22 February 2021

(C) The Author(s) 2021

\begin{abstract}
There is an increasing public awareness about the danger of dietary sugars with respect to their caloric contribution to the diet and the rise of overweight throughout the world. Therefore, low-calorie sugar substitutes are of high interest to replace sugar in foods and beverages. A promising alternative to natural sugars and artificial sweeteners is the fructose derivative 5-keto-D-fructose (5$\mathrm{KF}$ ), which is produced by several Gluconobacter species. A prerequisite before 5-KF can be used as a sweetener is to test whether the compound is degradable by microorganisms and whether it is metabolized by the human microbiota. We identified different environmental bacteria (Tatumella morbirosei, Gluconobacter japonicus LMG 26773, Gluconobacter japonicus LMG 1281, and Clostridium pasteurianum) that were able to grow with 5-KF as a substrate. Furthermore, Gluconobacter oxydans $621 \mathrm{H}$ could use $5-\mathrm{KF}$ as a carbon and energy source in the stationary growth phase. The enzymes involved in the utilization of 5$\mathrm{KF}$ were heterologously overproduced in Escherichia coli, purified and characterized. The enzymes were referred to as 5-KF reductases and belong to three unrelated enzymatic classes with highly different amino acid sequences, activities, and structural properties. Furthermore, we could show that 15 members of the most common and abundant intestinal bacteria cannot degrade 5$\mathrm{KF}$, indicating that this sugar derivative is not a suitable growth substrate for prokaryotes in the human intestine.
\end{abstract}

\section{Key points}

- Some environmental bacteria are able to use 5-KF as an energy and carbon source.

- Four 5-KF reductases were identified, belonging to three different protein families.

- Many gut bacteria cannot degrade 5-KF.

Keywords Dietary sugar $\cdot$ Artificial sweetener $\cdot$ Low-calorie sugar $\cdot$ Ketofructose reductase $\cdot$ Human microbiota $\cdot$ Sugar-related disease

\section{Introduction}

Several lines of evidence indicate that high sugar intake is a risk factor for the development of obesity, type 2 diabetes, and cardiovascular diseases (Malik et al. 2010; Schulze 2004). In addition, there is an increasing public awareness about the risk of dietary sugars (glucose, sucrose, and fructose) with respect

Jacqueline Schiessl and Konrad Kosciow contributed equally to this work.

Uwe Deppenmeier

udeppen@uni-bonn.de

1 Institute of Microbiology and Biotechnology, University of Bonn, Meckenheimer Allee 168, 53115 Bonn, Germany to their caloric contribution to the diet and the rise of overweight of children and adults throughout the world (Schulze 2004; Ludwig et al. 2001). Therefore, low-calorie sugar substitutes are of high interest to replace sugar in foods and beverages. Based on the tendency of increased human sugar intake and the associated negative effects on human metabolism, the demand for alternative sweeteners has increased enormously. Especially naturally occurring low-calorie sweeteners have become the focus of the food industry. Among the already established synthetic sweeteners are saccharin, acesulfame-K, sucralose, aspartame, and neotame (Mattes and Popkin 2009). Disadvantages of these synthetically produced sweeteners can be, for example, expensive synthesis processes, artificial tastes, or undesirable side effects for consumers (Schiffman et al. 1979; Wiet and Beyts 1992). Two 
other non-artificial sugar substitutes used in the food industry are the ketohexose tagatose and the sugar alcohol xylitol. Although both compounds have a high degree of sweetening, they can be partially metabolized by the human metabolism and therefore have a caloric value (Grembecka 2015; Vastenavond et al. 2011). Alternative sweeteners of natural origin are steviol glycosides, which have 30 to 150 times the sweetness of sugar. However, the compounds may have a bitter or licorice-like aftertaste (Soejarto et al. 1982). A promising alternative to natural sugars and artificial sweeteners is the bacterially produced fructose derivative 5-keto-D-fructose (D-threohexo-2,5-diulose, 5-KF). 5-KF is a natural sugar produced by acetic acid bacteria through oxidation of fructose by the membrane-bound enzyme fructose dehydrogenase (Ameyama et al. 1981; Kawai et al. 2013). The compound has the same natural taste as fructose without an artificial aftertaste and a sweetness comparable to sucrose (Herweg et al. 2018). In addition, 5-KF cannot or can only partially be metabolized by the human organism and thus has a very low-calorie content (Wyrobnik et al. 2009). The new potential sweetener has already been detected in various natural foods, including white wine, honey, and elderflower syrup (Burroughs and Sparks 1973; Blasi et al. 2008).

$5-\mathrm{KF}$ is produced by the oxidation of fructose by some representatives of acetic acid bacteria of the genus Gluconobacter. Some of the organisms, such as Gluconobacter (G.) japonicus, possess the enzyme fructose dehydrogenase, which can oxidize fructose to 5-KF (Ameyama et al. 1981; Yamada et al. 1966). The genes coding for fructose dehydrogenase were introduced into G. oxydans $621 \mathrm{H}$ (Siemen et al. 2018) and the resulting genetically modified strain was capable of producing $5-\mathrm{KF}$ in a fed-batch fermentation process resulting in product titers of up to $490 \mathrm{~g} \mathrm{~L}^{-1}$ and product yields up to $98 \%$ (Herweg et al. 2018). Furthermore, a $G$. oxydans strain was developed for the efficient production of 5-KF from the cost-efficient and renewable feedstock sucrose (Hoffmann et al. 2020). But before 5-KF can be used as a sweetener, it should be tested whether the compound is degradable by microorganisms and whether it is metabolized by the human microbiota. Therefore, we tested several bacteria for their ability to degrade 5-KF and we analyzed the enzymes involved in this process.

\section{Materials and methods}

\section{Materials}

All reagents, chemicals, and substrates used in this study were purchased from Carl Roth GmbH (Karlsruhe, Germany), Sigma-Aldrich (Taufkirchen, Germany), or Megazyme (Bray, Ireland). Q5 High-fidelity DNA polymerase, restriction endonucleases, T4 ligase, and PCR reagents were bought from Thermo Fisher Scientific Inc. (Waltham, USA) and New England Biolabs (Frankfurt am Main, Germany). Oligonucleotides were synthesized by Eurofins Scientific (Ebersberg, Germany).

\section{Culture conditions and standard molecular techniques}

G. oxydans strains, G. japonicus LMG 26773, G. japonicus LMG 1281, and Tatumella (T.) morbirosei DSM 23827 (Table 1) were cultivated at $30^{\circ} \mathrm{C}$ and $180 \mathrm{rpm}$. Precultures of Gluconobacter strains and T. morbirosei were grown in YM-medium ( $0.6 \%$ yeast extract, $0.9 \%$ mannitol) and in nutrient broth $(0.5 \%$ peptone, $0.3 \%$ meat extract), respectively. For growth experiments, a medium consisting of $0.6 \%$ yeast extract was used. 5-KF was added as indicated. Precultures of Clostridium (C.) pasteurianum were cultivated anaerobically in a complex peptone yeast (PY) medium (Dowell and Hawkins 1974) containing $20 \mathrm{mM}$ glucose in serum flasks under a $\mathrm{N}_{2} / \mathrm{CO}_{2}(80 / 20)$ atmosphere at $37^{\circ} \mathrm{C}$ without agitation. Growth experiments with $5-\mathrm{KF}$ were performed using a complex medium with $0.4 \%$ yeast extract, supplemented with $48 \mathrm{mM} \mathrm{NaHCO}_{3}, 5 \%$ modified mineral 3B solution $(40 \mathrm{mM}$ $\mathrm{KH}_{2} \mathrm{PO}_{4}, 300 \mathrm{mM} \mathrm{NaCl}, 4 \mathrm{mM} \mathrm{CaCl} \times 2 \mathrm{H}_{2} \mathrm{O}, 2 \mathrm{mM} \mathrm{MgCl}_{2}$ x $6 \mathrm{H}_{2} \mathrm{O}, 1 \mathrm{mM} \mathrm{MnCl} \mathrm{m}_{2} \times 4 \mathrm{H}_{2} \mathrm{O} 0.1 \mathrm{mM} \mathrm{CoCl}_{2} \times 6 \mathrm{H}_{2} \mathrm{O}$, $35 \mathrm{mM} \mathrm{Na}_{2} \mathrm{SO}_{4}$, (Varel and Bryant 1974)) $0.5 \mathrm{~g} \mathrm{~L}^{-1}$ cysteine and $25 \mathrm{mM}$ substrate, $\mathrm{pH} 7$, in serum flasks under $\mathrm{N}_{2}$ atmosphere. The $\mathrm{pH}$ was adjusted with $\mathrm{NaHCO}_{3}$. Escherichia (E.) coli $\mathrm{DH} 5 \alpha$ was cultivated in lysogeny broth (LB) (Miller 1972) at $37{ }^{\circ} \mathrm{C}, 180 \mathrm{rpm}$. Ampicillin $\left(100 \mu \mathrm{g} \mathrm{mL}{ }^{-1}\right)$ was added for plasmid maintenance.

\section{HPLC analysis}

For the analysis of substrate consumption and product formation analysis, 1-ml samples were taken at different time points and centrifuged at 13,000 $\times g$ for $1 \mathrm{~min}$. The supernatants were diluted 1:10 with $\mathrm{H}_{2} \mathrm{O}$. HPLC analysis (Knauer Smartline HPLC system, Knauer GmbH, Berlin, Germany) was performed using an Aminex HPX-87H $300 \mathrm{~mm} \times 7.8 \mathrm{~mm}$ column (Biorad, Munich, Germany) with $5 \mathrm{mM} \mathrm{H}_{2} \mathrm{SO}_{4}$ at $65^{\circ} \mathrm{C}$ and a flow rate of $0.6 \mathrm{ml} \mathrm{min}^{-1}$. Substrates and products were quantified by a refraction index detector (RI detector; Azura RID2.1 L, Knauer GmbH, Berlin, Germany) and a UV detector (Smartline 2600, Knauer, Berlin, Germany) at $210 \mathrm{~nm}$ by comparison to calibration curves. For product analysis of 5KF reduction enzyme assays samples were analyzed by a SpectraSYSTEM HPLC system (Thermo Fisher Scientific Inc., Waltham, USA) using an amino phase column Eurospher II $100 \mathrm{NH} 2(250 \times 3.0 \mathrm{~mm} ; 5 \mu \mathrm{m}$ particle size $)$ (Knauer GmbH, Berlin, Germany) with integrated precolumn, $90 \%$ acetonitrile as solvent, at $40^{\circ} \mathrm{C}$ and a flow rate of $0.6 \mathrm{ml}$ $\mathrm{min}^{-1}$. Products were quantified by a refraction index (RI) 
Table 1 Strains, plasmids, and primers

\begin{tabular}{|c|c|c|}
\hline Strain, plasmid, primer & Description & Source \\
\hline \multicolumn{3}{|l|}{ Strain } \\
\hline Clostridium pasteurianum DSM 525 & Wild-type strain & DSMZ (Braunschweig, Germany) \\
\hline $\begin{array}{l}\text { Escherichia coli } \mathrm{NEB} \circledast 5 \text {-alpha (re- } \\
\text { ferred } \\
\text { to as } E \text {. coli) }\end{array}$ & $\begin{array}{l}\mathrm{F}-, \text {, } 80 \mathrm{~d} \text { lacZ } \Delta \mathrm{M} 15, \Delta(\text { lacZYA-argF) } \mathrm{U} 169, \text { deoR, recA1, } \\
\quad \text { endA1, hsdR17 (rk-, mk+), phoA, supE44, } \lambda-, \text { thi-1, } \\
\quad \text { gyrA96, relA1 }\end{array}$ & $\begin{array}{l}\text { New England Biolabs } \\
\text { (Ipswich, USA) }\end{array}$ \\
\hline Escherichia coli pASK5_KFR_TM & E. coli $\mathrm{NEB} 囚$ 5-alpha containing plasmid pASK5_KFR_TM & This study \\
\hline Escherichia coli pASK5_gox0644 & E. coli $\mathrm{NEB} 囚$ 5-alpha containing plasmid pASK5_gox0644 & (Schweiger et al. 2010) \\
\hline Escherichia coli $\mathrm{pASK} .3$ gox $1432 . \mathrm{ST}$ & E. coli $\mathrm{NEB} \circledast 5$-alpha containing plasmid pASK.3_gox1432.ST & (Zahid and Deppenmeier 2016) \\
\hline Escherichia coli pASK5_AKR_Cpast & E. coli $\mathrm{NEB}{ }^{\circledR}$ 5-alpha containing plasmid pASK5_AKR_Cpast & This study \\
\hline Escherichia coli pASK5_SDH_Cpast & E. coli $\mathrm{NEB} \circledast 5$-alpha containing plasmid pASK5_SDH_Cpast & This study \\
\hline Escherichia coli pASK5_gox1615 & E. coli $\mathrm{NEB} 囚 5$-alpha containing plasmid pASK5_gox 1615 & (Schweiger et al. 2010) \\
\hline Escherichia coli pASK5_gox2684 & E. coli $\mathrm{NEB} 囚 5$-alpha containing plasmid pASK5_gox 2684 & (Schweiger et al. 2008) \\
\hline Escherichia coli pASK5_gox0502 & E. coli $\mathrm{NEB} 囚$ 5-alpha containing plasmid pASK5_gox 0502 & (Schweiger et al. 2008) \\
\hline Escherichia coli pASK5_gox0313 & E. coli $\mathrm{NEB} 囚 5$-alpha containing plasmid pASK5_gox 0313 & (Schweiger et al. 2013) \\
\hline Escherichia coli pASK3_gox0646 & E. coli $\mathrm{NEB} 囚 5$-alpha containing plasmid pASK3_gox0646 & (Schweiger et al. 2013) \\
\hline Escherichia coli pASK5_gox1417 & E. coli $\mathrm{NEB} 囚 5$-alpha containing plasmid pASK5_gox1417 & (Rauch et al. 2010) \\
\hline Gluconobacter japonicus LMG 1281 & Wild-type strain; $\mathrm{Cef}^{\mathrm{R}}$ & $\mathrm{BCCM}$ \\
\hline Gluconobacter japonicus LMG 26773 & Wild-type strain; $\mathrm{Cef}^{\mathrm{R}}$ & $\mathrm{BCCM}$ \\
\hline $\begin{array}{l}\text { Gluconobacter oxydans } 621 \mathrm{H} \Delta h s d R \\
\quad \text { (referred to as G. oxydans) }\end{array}$ & $\Delta h s d R(\Delta$ gox 2567) derivative of G. oxydans $621 \mathrm{H}$ & $\begin{array}{l}\text { S. Bringer-Meyer, } \\
\text { Forschungszentrum Jülich } \\
\text { GmbH }\end{array}$ \\
\hline Tatumella morbirosei DSM 23827 & Wild-type strain & $\begin{array}{l}\text { DSMZ } \\
\quad \text { (Braunschweig, Germany) }\end{array}$ \\
\hline \multicolumn{3}{|c|}{ 然 } \\
\hline pASK-IBA.3 & C-terminal Strep-tag II sequence, tetA promoter/repressor system, $A m p^{R}$ & IBA GmbH \\
\hline pASK5-IBA.5 & N-terminal Strep-tag II, tetA promoter/repressor system, $\mathrm{Amp}^{\mathrm{R}}$ & IBA GmbH \\
\hline pASK5_KFR_TM & pASK-IBA.5 containing the gene $k f r$ from T. morbirosei DSM 23827 & This study \\
\hline pASK5_gox0644 & pASK-IBA.5 containing the gene gox 0644 from $G$. oxydans $621 \mathrm{H} \Delta h s d R$ & (Schweiger et al. 2010) \\
\hline pASK.3_gox1432.ST & pASK-IBA. 3 containing the gene gox 1432 from $G$. oxydans $621 \mathrm{H} \Delta h s d R$ & (Zahid and Deppenmeier 2016) \\
\hline pASK5_AKR_Cpast & pASK-IBA. 5 containing the gene $a k r$ from $C$. pasteurianum DSM 525 & This study \\
\hline pASK5_SDH_Cpast & pASK-IBA. 5 containing the gene $s d h$ from C. pasteurianum DSM 525 & This study \\
\hline pASK5_gox1615 & pASK-IBA.5 containing the gene gox 1615 from $G$. oxydans $621 \mathrm{H} \Delta h s d R$ & (Schweiger et al. 2010) \\
\hline pASK5_gox2684 & pASK-IBA. 5 containing the gene gox 2684 from G. oxydans $621 \mathrm{H} \Delta h s d R$ & (Schweiger et al. 2008) \\
\hline pASK5_gox0502 & pASK-IBA. 5 containing the gene gox 0502 from $G$. oxydans $621 \mathrm{H} \Delta h s d R$ & (Schweiger et al. 2008) \\
\hline pASK5_gox0313 & pASK-IBA.5 containing the gene gox 0313 from G. oxydans $621 \mathrm{H} \Delta h s d R$ & (Schweiger et al. 2013) \\
\hline pASK3_gox0646 & pASK-IBA.3 containing the gene gox 0646 from $G$. oxydans $621 \mathrm{H} \Delta h s d R$ & (Schweiger et al. 2013) \\
\hline pASK5_gox0417 & pASK-IBA.5 containing the gene gox 0417 from G. oxydans $621 \mathrm{H} \Delta h s d R$ & (Rauch et al. 2010) \\
\hline Primers & Primer sequence $\mathrm{a}^{\mathrm{a}}$ & Restriction site \\
\hline KFR_pASK5_for & ATTAGAATTCTGCTGAACAACAAAAT & EcoRI \\
\hline KFR_pAKS5_rev & TAAT $\overline{\overline{C T C G A G} T C A G C C G G T G A A A A G T}$ & XhoI \\
\hline AKR_Cpast_for & $\begin{array}{l}\text { ATGGTAGGTCTCAGCGCGCCGTAAAATCTATTAAGGATGTTATA } \\
\text { ACTT }\end{array}$ & BsaI \\
\hline AKR_Cpast_rev & ATGGTAGGTCTCATATCACATCTGAA & $B s a \mathrm{I}$ \\
\hline SDH_Cpast_for & ATGGTA $\overline{\overline{G G T C T C}}$ AGCGCCATGACATGTTTATTTGGACTTATAGG & BsaI \\
\hline SDH_Cpast_rev & $\begin{array}{l}\text { ATGGTA } \overline{\overline{G G T C T C}} \text { ATATCATATTTGTTTTTTTAAAAATTTGTCAT } \\
\text { ATATT }\end{array}$ & BsaI \\
\hline
\end{tabular}

${ }^{\mathrm{a}}$ Restriction sites are underlined

detector (Shodex RI-101) (Showa Denko Europe GmbH, Munich, Germany) and evaluated by the external standard method with ChromQuest 5.0 (Thermo Fisher Scientific Inc.).

\section{Construction of expression systems for $k f r$ and $a k r$}

The gene $k f r$ from T. morbirosei (HA49_09215) and $s d h$ from C. pasteurianum (CPAST_c38270), both encoding a putative shikimate dehydrogenase, and the gene $a k r$
(CPAST_c22030), encoding an aldo/keto-reductase (AKR) from C. pasteurianum, were amplified by PCR using Q5 High-fidelity DNA polymerase and the primers KFR_pASK5_for/ KFR_pASK5_rev, SDH_Cpast_for/ SDH_Cpast_rev, and AKR_Cpast_for/ AKR_Cpast_rev, respectively (Table 1). As template genomic DNA of T. morbirosei DSM 23827 and genomic DNA of C. pasteurianum DSM 525 was used. The genes were cloned into a pASK-IBA. 5 vector. The gene $k f r$ from $T$. morbirosei 
was cloned via the restriction sites $E c o$ RI and $X h o \mathrm{I}$ resulting in the plasmid construct pASK5_KFR_TM. The genes $s d h$ and $a k r$ from $C$. pasteurianum were cloned via the restriction site $B s a \mathrm{I}$, resulting in the vector constructs pASK5_SDH_Cpast and pASK5_AKR_Cpast, respectively. The plasmids were transformed into competent $E$. coli $\mathrm{DH} 5 \alpha$ cells by heat shock. Positive clones were verified by sequencing.

\section{Overexpression and purification of the proteins TM- KFR, CP-AKR, G0X0644, and G0X1432}

For protein production, overnight cultures of $E$. coli $(5 \mathrm{~mL})$ harboring plasmids of interest were used to inoculate $1 \mathrm{~L} \mathrm{LB}$ medium and were incubated at $37^{\circ} \mathrm{C}$ and $180 \mathrm{rpm}$ in shaker flasks. After reaching an $\mathrm{OD}_{600}$ of 0.4 , protein production was induced by the addition of $0.2 \mu \mathrm{g} \mathrm{mL}^{-1}$ anhydrotetracycline and cells were further cultivated for $4 \mathrm{~h}$. Cultures were harvested at $\mathrm{OD}_{600}$ between 1.0 and 1.5 by centrifugation $\left(9000 \times g, 4{ }^{\circ} \mathrm{C}, 15 \mathrm{~min}\right)$. Lysis and purification were performed by sonication as previously described (Kosciow et al. 2016). For protein visualization, polyacrylamide gel electrophoresis was done according to (Laemmli 1970) and protein bands were detected via silver stain as described by (Blum et al. 1987). Analysis of the native conformation of the ketofructose reductases was performed by gel filtration chromatography using a HiLoad 16/60 Superdex 200 pg column (GE Healthcare, Chicago, USA) connected to an ÄKTApurifier system (GE Healthcare, Chicago, USA). The column was calibrated using the Gel Filtration Calibration Kit HMW (GE Healthcare, Chicago, USA). Equilibration was done with $50 \mathrm{mM}$ Tris- $\mathrm{HCl}$ buffer $\mathrm{pH} 8$, containing $150 \mathrm{mM} \mathrm{NaCl}$.

\section{Measurement of enzyme activities and kinetic parameters}

The reduction of 5-KF and other substrates accompanied by the oxidation of $\mathrm{NAD}(\mathrm{P}) \mathrm{H}$ to $\mathrm{NAD}(\mathrm{P})^{+}$was recorded at $340 \mathrm{~nm}\left(\varepsilon=6.22 \mathrm{mM}^{-1} \mathrm{~cm}^{-1}\right)$. The reaction mixture with a final volume of $1 \mathrm{ml}$ contained $250 \mu \mathrm{M}$ NAD(P)H, $40 \mathrm{mM}$ potassium phosphate buffer ( $\mathrm{pH} 7$ ), and varying substrate concentrations between 5 and $20 \mathrm{mM}$. One unit of enzyme activity corresponded to the oxidation of $1.0 \mu \mathrm{mol}$ of substrate per min and $\mathrm{mg}$ protein. The $\mathrm{pH}$ optima were determined using the McIlvaine buffer system (Mcllvaine 1921) between $\mathrm{pH}$ 3.0 and 9.0 containing disodium phosphate and citric acid. Temperature optima were analyzed in a temperature range between $20^{\circ} \mathrm{C}$ and $80{ }^{\circ} \mathrm{C}$ using standard assay conditions. Nonlinear regressions of Michaelis-Menten data were used to calculate kinetic constants at optimal $\mathrm{pH}$ and temperate using 5-KF concentrations between 0.5 and $80 \mathrm{mM}$ and $\mathrm{NAD}(\mathrm{P}) \mathrm{H}$ concentrations between $5 \mu \mathrm{M}$ and $250 \mu \mathrm{M}$, respectively.
Enzyme assays analyzed via HPLC were performed with the same principle as described above. The enzyme assays had a final volume of $250 \mu \mathrm{L}$ with $5 \mathrm{mM}$ NADPH, $5 \mathrm{mM} 5-\mathrm{KF}$, $40 \mathrm{mM}$ potassium phosphate buffer $\mathrm{pH} 7$ or $\mathrm{pH} 6$ for $\mathrm{CP}-\mathrm{AKR}$ and $2 \mu \mathrm{g}$ enzyme. The reaction mixture was incubated at 30 ${ }^{\circ} \mathrm{C}$ or $40{ }^{\circ} \mathrm{C}$ for $\mathrm{CP}$-AKR for three hours. The enzyme reaction assays were directly analyzed via HPLC, as described above.

\section{Transcriptional analysis by qRT-PCR experiments}

Total RNA from T. morbirosei, C. pasteurianum, or G. japonicus LMG 23776 was isolated from $50 \mathrm{ml}$ cultures grown to mid-exponential phase as described by Kröninger et al. (2017). qRT-PCR reactions were performed with a CAPITAL $^{\text {TM }}$ qRT-PCR Green Mix One Step Kit (Biotechrabbit, Hennigsdorf, Germany), which uses SYBR Green as the fluorescent dye. Each PCR reaction contained $150-200 \mathrm{ng}$ of purified RNA. Temperature cycling and fluorescence measurement was performed with a cycler CFX Connect ${ }^{\mathrm{TM}}$ and suitable software (BioRad, Munich, Germany). The $\Delta \mathrm{Ct}$ values were calculated by subtraction of the quantification cycle $(\mathrm{Ct})$ of the reference gene (encoding the 50S ribosomal protein $\mathrm{L} 10$ ) from the $\mathrm{Ct}$ value of each gene of interest. The relative change in mRNA abundance was recorded as the ratio of normalized target concentrations $(\Delta \Delta \mathrm{Ct})$. The fold change of each gene was calculated using the formula $2^{-\Delta \Delta \mathrm{Ct}}$. The following genes were analyzed: T. morbirosei gene HA49_09215 encoding protein KGD75378 (TM-KFR; primers KFR_fw: CGGCGACC TATGTTGAATGG and KFR_rev: GGAAGCAGCACGTA ACAG AG), T. morbirosei gene HA49_21310 encoding the 50S ribosomal protein L10 as reference gene (primers T.morb_rib50S_fw: TCGTGAAGCTGGCGTATACA and T.morb_rib50S_rev: TTTGAACAGACGAG CAGCAG), C. pasteurianum gene CPAST_c22030 encoding protein AJA48273.1 (CP-AKR; primers C.past_AKR_fw: CGGAAGGGGTGCTGTTCTTA and C.past_AKR_rev: TCCCCAGTTCTTTCAGCTC T), C. pasteurianum gene CLPA_c36850 encoding the 50S ribosomal protein L10 as reference gene (primers: C.past_rib50S_fw: CGTGCTGC AAATGAACTTGG and C.past_rib50S_rev: CGCCTTGTA CTAATCCAGCC), G. japonicus LMG 26773 gene AD942_05425 encoding protein KXV40663 (GJA0644; primers G.jap-1-_KFR_fw: GCACTTGTTGACCT GCAGAA and G.jap-1-_KFR_rev: TGCGGATGTTATGC TGTTCG), G. japonicus LMG 26773 gene AD942_03970 encoding protein KXV41067 (GAJ1432; primers: G.jap-2KFR fw: GATCTGAAGACGCCGGAAAC and G.jap-2KFR_rev: GATGCGATCAACCATGCCAT), and G. japonicus LMG 26773 gene AD935_10055 encoding the 50S ribosomal protein L10 as reference gene (primers: G.jap_rib50S_fw: AGAACAAGGGTCTGACGGTT and G.jap_rib50S_rev: AGCTTGTCATTCGTCTTGGC). 


\section{Bioinformatic tools}

The program Blastp at the NCBI database (https://blast.ncbi. nlm.nih.gov/Blast.cgi) was used to identify proteins and to compare amino acid sequences (Johnson et al. 2008). The term similarity is defined as percentage of the number of amino acids that were either identical between the query and the subject sequence or had similar chemical properties. Amino acid sequence alignments were performed with the program Clustal Omega (https://www.ebi.ac.uk/Tools/msa/clustalo/) using default parameters. Kinetic parameters of purified enzymes were determined using nonlinear regression of the Michaelis-Menten data with the program GraphPad Prism Version 9.0.0

\section{Results}

\section{5-KF consumption in aerobic bacteria}

It was already shown that $T$. citrea (former Erwinia citreus) is capable of reducing $5-\mathrm{KF}$. The organism possesses a 5-KF reductase, which catalyzes the reversible NADPH-dependent reduction of 5-KF to D-fructose (Schrimsher et al. 1988). We tested a close relative, T. morbirosei, for its ability to grow on $5-\mathrm{KF}$ as a carbon and energy source. A complex medium was used for the growth experiments since no mineral medium is available for T. morbirosei and the growth requirements of this organism are unknown. In the control experiment without the addition of a sugar source, the cells grew to an optical density $\left(\mathrm{OD}_{600}\right)$ of 1.25 within $20 \mathrm{~h}$ (Fig. 1). The doubling time $\left(\mathrm{t}_{\mathrm{d}}\right)$ was $2.3 \mathrm{~h}$. Cultures with $5-\mathrm{KF}$ revealed a similar growth pattern at the beginning of the experiment $\left(t_{d}=1.8\right.$

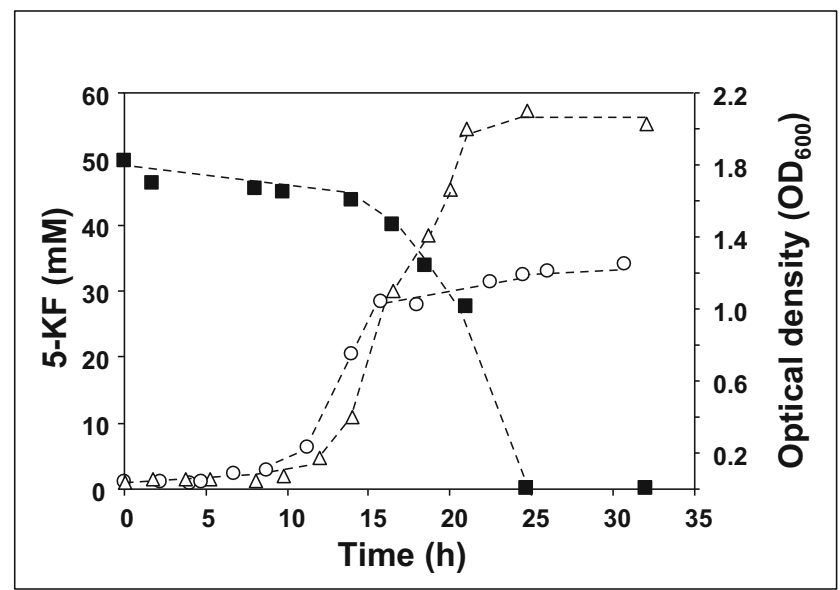

Fig. 1 Growth and 5-KF consumption in T. morbirosei. Cells were grown in $0.6 \%$ yeast extract with $50 \mathrm{mM} 5-\mathrm{KF}$ or without $5-\mathrm{KF}$ at 30 ${ }^{\circ} \mathrm{C}$. ( ) $5-\mathrm{KF}$ concentration, $(\Delta) \mathrm{OD}_{600}$ of $5-\mathrm{KF}$ containing cultures, $(\mathrm{O})$ $\mathrm{OD}_{600}$ of control cultures without 5-KF. The figure shows a representative experiment from three biological replicates (for additional experiments see Fig. S1) h) with a short slowdown of growth after $16 \mathrm{~h}$. In contrast to the negative control, a second growth was observed and the $\mathrm{OD}_{600}$ increased to 2.1 (Fig. 1), indicating a typical pattern of diauxic growth. In line with this observation was the fact that the organism consumed significant amounts of $5 \mathrm{KF}$ only after $16 \mathrm{~h}$. 5-KF was completely utilized after $25 \mathrm{~h}$ and cells turned into the stationary growth phase. It can therefore be assumed that components of the complex medium were first used for growth, as in the control without 5-KF. Only in the second phase, 5-KF was utilized, which was accompanied by an increased $\mathrm{OD}_{600}$. T. morbirosei was therefore able to use 5-KF as a substrate.

Some species of the genus Gluconobacter are known to produce 5-KF from fructose. The membrane-bound fructose dehydrogenase (Fdh), which is encoded by the $f d h S C L$ genes, plays a crucial role in this process (Kawai et al. 2013). The enzyme oxidizes fructose at the hydroxyl group at position 5 , thus forming 5-KF and transferring the released electrons into the respiratory chain of the organism. The resulting 5-KF diffuses via porins in the outer membrane into the extracellular space and accumulates in the culture supernatant. Hence, the question arose whether 5-KF can also be a substrate for growth. For this purpose, the Fdh-producing strain G. japonicus LMG 26773 was tested, which is able to form 5 -KF. The organism was grown on a medium containing $0.6 \%$ yeast extract and $25 \mathrm{mM} \mathrm{5-KF} \mathrm{(Fig.} \mathrm{2).} \mathrm{It} \mathrm{was} \mathrm{found} \mathrm{that}$ G. japonicus LMG 26773 consumed large quantities of 5$\mathrm{KF}$ after a lag phase of about $3 \mathrm{~h}$ and almost completely converted the substrate after $12 \mathrm{~h}$. The $\mathrm{OD}_{600}$ increased from 0.05 to 2.2 within $9 \mathrm{~h}$ and the doubling time was $1.3 \mathrm{~h}$. The control culture without $5-\mathrm{KF}$ addition showed only an increase in $\mathrm{OD}_{600}$ from 0.05 to 0.2 (Fig. 2).

The model organism G. oxydans $621 \mathrm{H}$ does not possess the key enzyme Fdh for 5-KF production (Siemen et al. 2018).

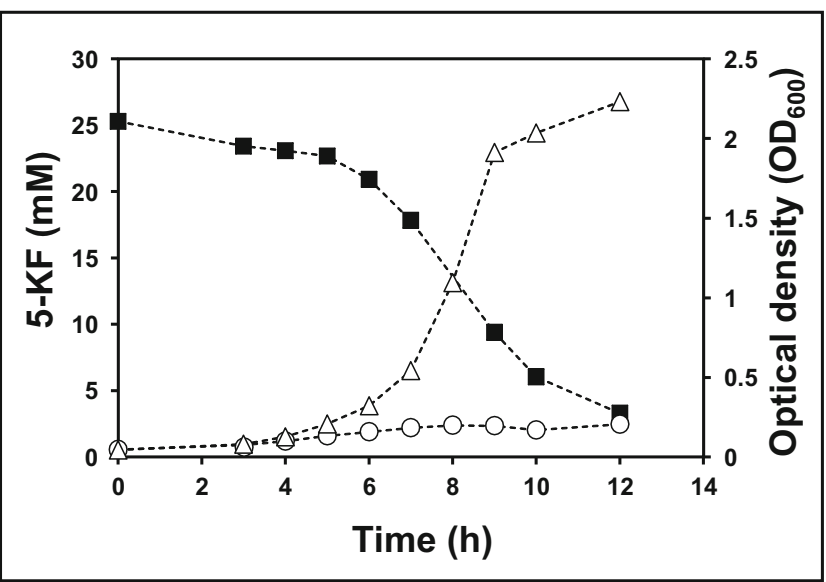

Fig. 2 Growth of G. japonicus LMG 26773. Cells were grown in $0.6 \%$ yeast extract with $25 \mathrm{mM} 5-\mathrm{KF}$ or without $5-\mathrm{KF}$ at $30^{\circ} \mathrm{C}$. (- $5-\mathrm{KF}$ concentration, $(\Delta) \mathrm{OD}_{600}$ in the presence of $5-\mathrm{KF},(\circ) \mathrm{OD}_{600}$ in the absence of 5-KF. One out of three independent experiments is shown (for additional information, see Fig. S2) 
Therefore, we tested a $f d h$ knock-in mutant of G. oxydans (Hoffmann et al. 2020) for the expression of the $f d h$ genes that allowed the production of the fructose dehydrogenase. Two other strains G. japonicus LMG 1281 and G. japonicus LMG 26773 naturally contained the $f d h$ genes on their chromosomes (gene no. BAM93250 - BAM93252 and KXV40773 - KXV40775, respectively). As expected, all strains grew with fructose as substrate and accumulated $5-\mathrm{KF}$ in the culture supernatant up to a concentration of $50 \mathrm{mM}$ (Hoffmann et al. 2020). In the stationary phase, G. japonicus LMG 1281 and G. japonicus LMG 26773 completely consumed 5-KF within the period $40-98 \mathrm{~h}$ and $40-70 \mathrm{~h}$, respectively (Fig. 3). In G. oxydans $f d h$ the degradation of 5-KF was slow and only $10 \mathrm{mM} 5-\mathrm{KF}$ were utilized within $60 \mathrm{~h}$.

\section{5-KF consumption in anaerobic bacteria}

All 5-KF degrading species described above were strict aerobes and needed $\mathrm{O}_{2}$ as the final acceptor of their respiratory chain. Hence, the question arose whether only aerobic bacteria are able to ferment $5-\mathrm{KF}$ or whether this ability is also observed in anaerobic bacteria. As a model organism we tested $C$. pasteurianum DSM 525 for its ability to use $5-\mathrm{KF}$ as a substrate. The organism reached an $\mathrm{OD}_{600}$ of 1.7 and a doubling time of $2.0 \mathrm{~h}$ with $25 \mathrm{mM}$ glucose as its preferred carbon source. In contrast, $C$. pasteurianum grew to a final $\mathrm{OD}_{600}$ of 1.4 within $17.5 \mathrm{~h}$ in the presence of $23 \mathrm{mM} 5-\mathrm{KF}$, which corresponded to a growth rate of $0.33 \mathrm{~h}^{-1}$ and a doubling time of $2.1 \mathrm{~h}$ in the exponential phase (Fig. 4). HPLC analysis revealed a complete consumption of 5-KF after $17.5 \mathrm{~h}$ and the synthesis of the

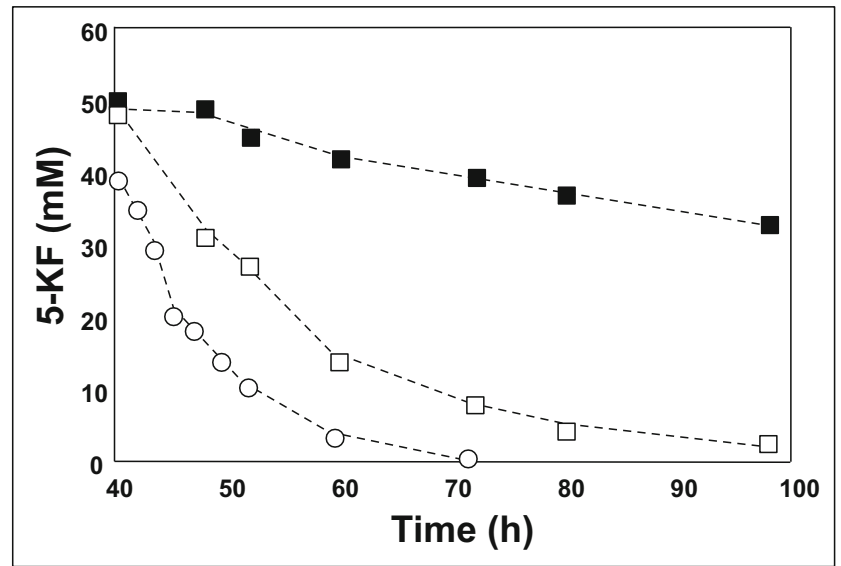

Fig. 3 Degradation of 5-KF in the stationary growth phase by different Gluconobacter strains grown on $0.6 \%$ yeast extract and fructose as substrate. (ロ) G. oxydans fdh, () G. japonicus LMG 1281, (०) G. japonicus LMG 26773. The experiment was conducted in triplicate. 5-KF was added to a final concentration of $50 \mathrm{mM}$. The figure shows a representative experiment from three biological replicates (additional experiments are shown in Fig. S3)

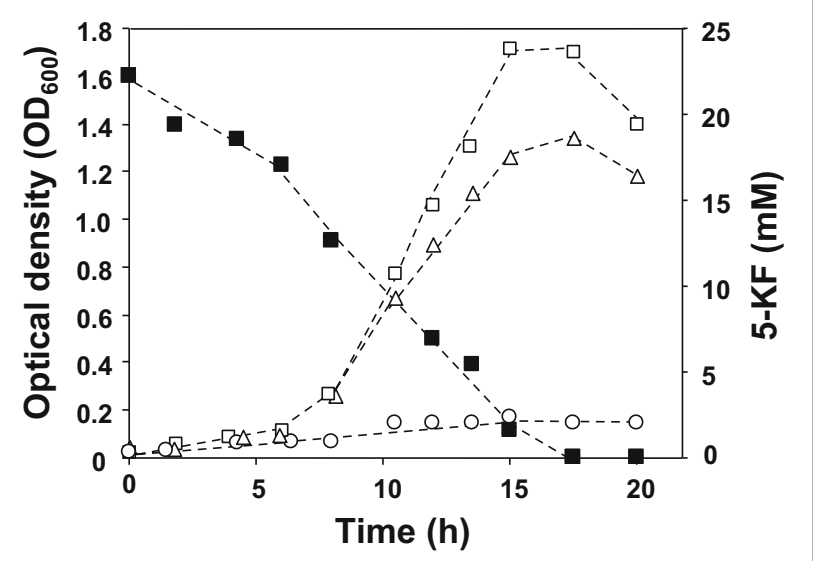

Fig. 4 Growth and 5-KF consumption in C. pasteurianum. Cells were grown at $37^{\circ} \mathrm{C}$ in $0.4 \%$ yeast extract medium supplemented with $48 \mathrm{mM}$ $\mathrm{NaHCO}_{3}$, modified mineral 3B solution, and $23 \mathrm{mM} \mathrm{5-KF}$ or $23 \mathrm{mM}$ glucose. ( $\mathbf{\square}) 5-\mathrm{KF}$ concentration, $(\Delta) \mathrm{OD}_{600}$ of 5-KF containing cultures, (○) $\mathrm{OD}_{600}$ of control cultures without carbon source, $(\square) \mathrm{OD}_{600}$ of glucose grown cultures. One out of three independent experiments is shown (the other experiments are shown in Fig. S4)

expected end products butyrate and acetate, indicating that this compound was metabolized by $C$. pasteurianum. Without an additional carbon source, $C$. pasteurianum reached only a final $\mathrm{OD}_{600}$ of 0.15 (Fig. 4).

Since we could show that the anaerobic bacterium C. pasteurianum is able to metabolize $5-\mathrm{KF}$, the next step was the investigation of whether the main players of the anaerobic human gut microbiota also have the ability to use 5$\mathrm{KF}$ as a carbon and energy source. For consumers and the food industry, these experiments are important as they allow the determination of the effective caloric value of novel and potential sweeteners. Thus, 15 microorganisms were tested as representatives of important members of the human gut microbiota: Agathobacter rectalis DSM 17629, Akkermansia muciniphila DSM 22959, Alistipes shahii DSM 19121, Bacteroides vulgatus DSM 1447, Bifidobacterium adolescentis DSM 20083, Clostridium leptum DSM 753, Collinsella intestinalis DSM 13280, Dorea formicigenerans DSM 3992, E. coli K12, Eubacterium siraeum DSM 15702, Lactobacillus reuteri DSM 17509, Methanomassiliicoccus luminyensis DSM 25720, Parabacteroides johnsonii DSM 18315, Prevotella copri DSM 18205 and Ruminococcus gnavus DSM 108212 (Tab. S1). However, it became evident that the tested organisms did not reach a higher $\mathrm{OD}_{600}$ with $20 \mathrm{mM} \mathrm{5-KF}$ as substrate when compared to the negative control without an additional carbon source (Fig. S5). Furthermore, HPLC analysis confirmed that 5-KF was not degraded by these bacteria. The results indicated that many important microbial species within the human gut are likely not able to metabolize 5-KF and to produce short-chain fatty acids, which could contribute to the total calorie intake of the human body. 


\section{Characterization of 5-KF reductases}

As shown above, a couple of bacteria can grow with 5-KF as carbon and energy source. Others were able to use the compound in the stationary phase to ensure survival in their substrate-limited habitat. However, the knowledge about biochemical reactions that are involved in 5-KF degradation is limited. It is known that $T$. citrea contains a $5-\mathrm{KF}$ reductase that can reduce 5-KF using NADPH as reductant. The corresponding enzyme was purified and characterized (Schrimsher et al. 1988). The $\mathrm{N}$-terminal AS sequence was published and a BLASTx search (https://blast.ncbi.nlm.nih.gov/Blast.cgi) resulted in the identification of protein from T. morbirosei with $94 \%$ similarity. Hence, we could identify the corresponding gene (HA49_09215) and amino acid sequence (KGD75378.1). The corresponding DNA fragment was amplified by PCR and the gene was cloned into plasmid pASK-IBA.5, which allowed the precise fusion with the vector encoded Strep-tag II sequence. The protein was produced in E. coli and purified to apparent homogeneity with the help of a streptavidin affinity column (Fig. 5). The protein was referred to as TM-KFR.

As demonstrated by SDS-PAGE (Fig. 5), TM-KFR showed the expected protein band with a molecular mass of $38 \mathrm{kDa}$. The native protein revealed a single active peak when analyzed by gel filtration. The peak corresponded to 121.3
$\mathrm{kDa}$, indicating that the enzyme is active as a trimer (Table 2). The apparent $K_{M}$ value of the enzyme for 5-KF, estimated by using several concentrations of the substrate from 0.5 to $40 \mathrm{mM}$, was $6.4 \pm 0.6 \mathrm{mM}$ at $\mathrm{pH} 7.0$ and $30{ }^{\circ} \mathrm{C}$ (Table 2), while $\mathrm{V}_{\max }$ was $1522.8 \pm 141.9 \mathrm{U} \mathrm{mg}^{-1}$. The apparent $\mathrm{K}_{\mathrm{M}}$ value for NADPH was $20.4 \pm 11.5 \mu \mathrm{M}$. For a detailed analysis of enzymatic activities, we first determined the substrate spectrum of the protein. It became evident that the enzyme only reduced 5-KF and could only utilize NADPH as cofactor. All other compounds tested (aldehydes, ketones, sugars, keto sugars, sugar acids, polyols, Table 3) were not attacked. Hence, the specificity towards 5-KF can be used to determine the presence and concentration of the alternative sweetener in various foods and beverages in a photometric assay. Such tests were performed and it was found that 5-KF is present in different white wines, honey, and vinegar in micromolar concentrations (not shown).

As shown above, G. oxydans was not able to use 5-KF as carbon and energy source in the exponential growth phase, but consumption of $5-\mathrm{KF}$ was observed in the stationary phase (Fig. 3). To verify which enzymes are responsible for this effect, we tested several oxidoreductases that act on organic compounds containing keto groups for their ability to reduce 5-KF to fructose. All enzymes indicated in Fig. 6 were heterologously produced in E. coli and purified by Strep-tag affinity chromatography. It became evident that the 5-
Fig. 5 SDS-PAGE analysis of reductases. Lane 1 and 6 : PageRuler ${ }^{\mathrm{TM}}$ Prestained Protein Ladder (Thermo Fisher Scientific), Lane 2: CP-AKR (1 $\mu$ g protein). Lane 3: GOX1432 (2 $\mu \mathrm{g}$ protein). Lane 4: GOX0644 ( $2 \mu \mathrm{g}$ protein). Lane 5: TM-KFR (4 $\mu \mathrm{g}$ protein)

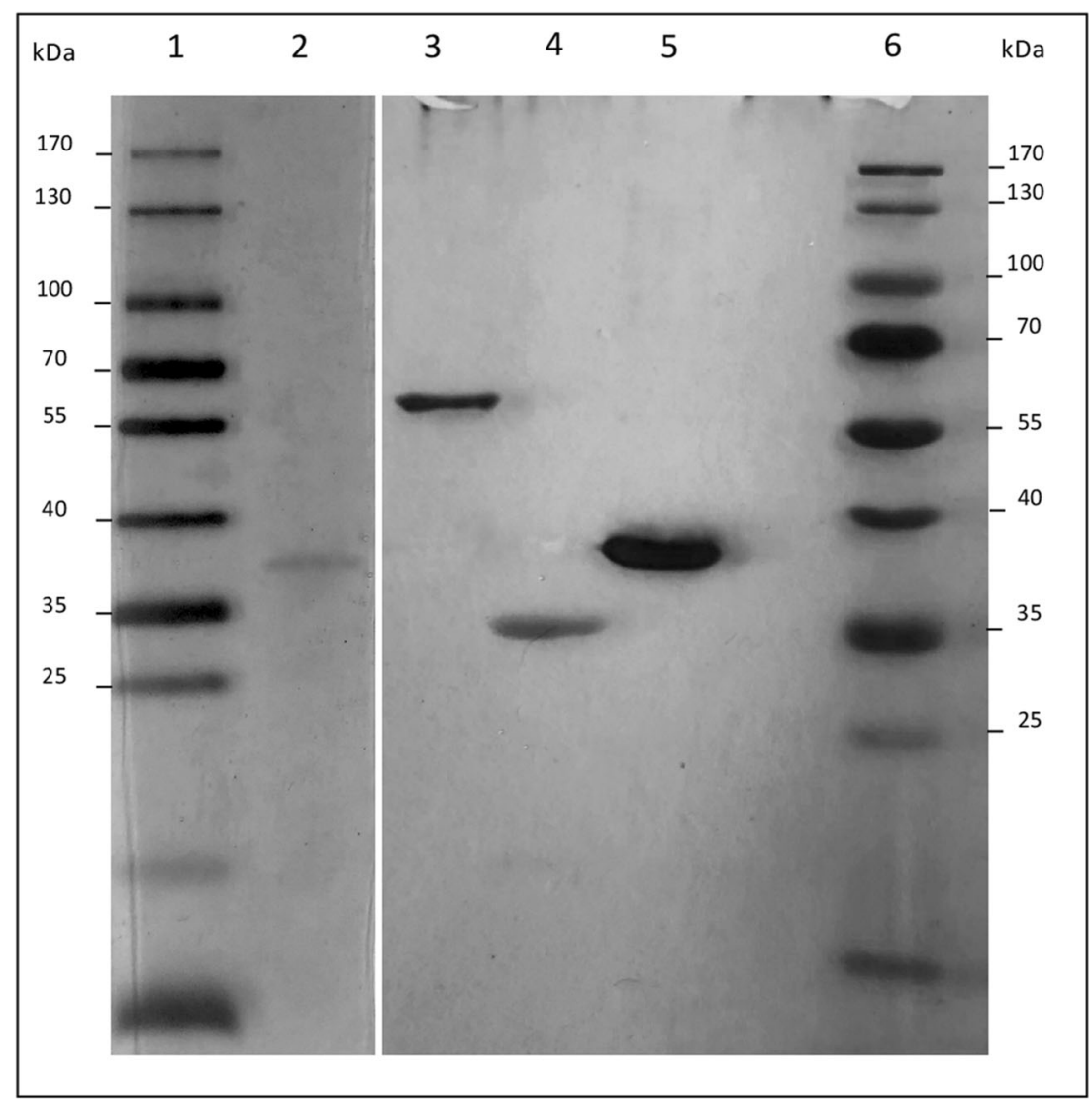


Table 2 Properties of 5-KF reducing enzymes

\begin{tabular}{|c|c|c|c|c|c|c|c|c|c|}
\hline Organism & Enzyme & $\begin{array}{l}\text { Monomer } \\
{[\mathrm{kDa}]^{1}}\end{array}$ & Conformation & $\begin{array}{l}\text { Temp.- } \\
\text { optimum } \\
{\left[{ }^{\circ} \mathrm{C}\right]}\end{array}$ & $\begin{array}{l}\mathrm{pH}- \\
\text { Optimum }\end{array}$ & $\begin{array}{l}\text { Specific } \\
\text { activity } \\
{[\mathrm{U} / \mathrm{mg}]}\end{array}$ & $\mathrm{K}_{\mathrm{cat}}\left[\mathrm{s}^{-1}\right]$ & $\begin{array}{l}\mathrm{K}_{\mathrm{M} \mathrm{5-KF}} \\
{[\mathrm{mM}]}\end{array}$ & $\begin{array}{l}\mathrm{K}_{\mathrm{M}} \mathrm{NADPH} \\
{[\mu \mathrm{M}]}\end{array}$ \\
\hline T. morbirosei & TM-KFR & 36.0 & trimer & 30 & 7 & $\begin{array}{r}1522.8 \\
\quad \pm 141.9\end{array}$ & $\begin{array}{c}913.9 \pm \\
85.2\end{array}$ & $6.4 \pm 0.6$ & $20.4 \pm 11.5$ \\
\hline G. oxydans & GOX0644 & 34.6 & dimer & 35 & 7 & $32.7 \pm 2.1$ & $18.9 \pm 1.2$ & $4.0 \pm 0.8$ & $61.2 \pm 11.4^{2}$ \\
\hline G. oxydans & GOX1432 & 55.9 & monomer & 30 & 7 & $230.3 \pm 8.0$ & $214.6 \pm 7.5$ & $42.0 \pm 5.4$ & $19.5 \pm 1.0^{3}$ \\
\hline C. pasteurianum & CP-AKR & 35.9 & tetramer & 40 & 6 & $48.9 \pm 7.1$ & $29.3 \pm 4.3$ & $1.3 \pm 0.2$ & $12.4 \pm 3.8$ \\
\hline
\end{tabular}

${ }^{1}$ Molecular mass including Strep-tag

${ }^{2}$ Schweiger et al. 2010

${ }^{3}$ Zahid and Deppenmeier 2016

ketogluconate reducing enzyme GOX1432 (Zahid and Deppenmeier 2016) and the $\alpha$-ketocarbonyl reductase GOX0644 (Schweiger et al. 2010) were able to reduce 5-KF with NADPH as reductant (Fig. 6). The $\alpha$-diketone reductase GOX0646 (Schweiger et al. 2013) reduced 5-KF at a very low rate. In contrast, the 2-ketogluconate reductase GOX0417 (Rauch et al. 2010) and the vinyl ketone reductases GOX0502 and GOX2684 (Schweiger et al. 2008) did not reduce $5-\mathrm{KF}$. The same was true for the $\alpha$-ketocarbonyl reductases GOX1615 (Schweiger et al. 2010) and GOX0313 (Schweiger et al. 2013) (Fig. 6).

SDS-PAGE analysis showed molecular masses of $34 \mathrm{kDa}$ and $55 \mathrm{kDa}$ for the proteins GOX0644 and GOX1432, respectively (Fig. 5), which were in good correlation with the estimated masses predicted from their amino acid sequences. The native conformation of both enzymes was analyzed via gel filtration, indicating a monomeric structure for protein GOX1432 and a dimeric conformation for protein GOX0644. Kinetic properties of the enzymes with 5-KF as substrate were examined with nonlinear regressions of Michaelis-Menten data. The $\mathrm{K}_{\mathrm{M}}$ and $\mathrm{V}_{\max }$ values of protein GOX0644 for 5-KF as substrate were $4.0 \pm 0.8 \mathrm{mM}$ and 32.7 $\pm 2.1 \mathrm{U} \mathrm{mg}^{-1}$ (Table 2). In case of protein GOX1432, a $\mathrm{V}_{\max }$ value of $230.3 \pm 8.0 \mathrm{U} \mathrm{mg}^{-1}$ was calculated, which indicates a higher specific activity for 5-KF when compared to GOX0644. In contrast, protein GOX1432 showed a significantly lower affinity for this substrate $\left(\mathrm{K}_{\mathrm{M}}\right.$ value: $42.0 \pm 5.4$ $\mathrm{mM}$; Table 2). With NADPH as co-substrate of the reaction, $\mathrm{K}_{\mathrm{M}}$ values of $61.2 \pm 11.4 \mu \mathrm{M}$ and $19.5 \pm 1.0 \mu \mathrm{M}$ were determined, respectively. The substrate spectra of the enzymes were already published. Protein GOX0644 reduced $\alpha$ ketoaldehydes, $\alpha$-diketones, $\alpha$-keto esters (Table 3), and the
Table 3 Analysis of the substrate spectrum of 5-KF reductases

\begin{tabular}{|c|c|c|c|c|c|}
\hline & & Specific a & $\mathrm{y}\left[\mathrm{U} \mathrm{mg}{ }^{-1}\right]$ & & \\
\hline & Substrates $^{1}$ & TM-KFR & GOX0644 & CP-AKR & GOX1432 \\
\hline \multirow[t]{3}{*}{ Ketones } & 2-butanol-3-one & 0 & 0 & 0.2 & 0 \\
\hline & 1-phenyl-1,2-propandione & 0 & 71.2 & 5.3 & 0 \\
\hline & pentane-2,3-dione & 0 & 20 & 0 & 0 \\
\hline \multirow[t]{4}{*}{ Aldehydes } & diacetyl & 0 & 14.3 & 13.5 & 0 \\
\hline & D-/L-glyceraldehyde & 0 & 0.1 & 0 & 0 \\
\hline & oxalaldehyde & 0 & 1.1 & 0.4 & 0 \\
\hline & pyruvaldehyde & 0 & 10.8 & 1.9 & 0 \\
\hline \multirow[t]{3}{*}{ Ketosugars } & 5-ketofructose & 1428 & 29.5 & 35.6 & 130 \\
\hline & 5-ketogluconate & 0 & 0 & 0.1 & 0.6 \\
\hline & L-sorbosone & 0 & 0 & 0.2 & 0 \\
\hline \multirow[t]{2}{*}{ Sugars } & D-fructose & 0 & 0 & 0 & 17.2 \\
\hline & L-sorbose & 0 & 0 & 0 & 6.8 \\
\hline
\end{tabular}

${ }^{1}$ Enzyme assays were performed at $30{ }^{\circ} \mathrm{C}$ in $1 \mathrm{ml}$ assays containing $40 \mathrm{mM}$ potassium phosphate buffer $\mathrm{pH} 7$ or $\mathrm{pH} 6$ for CP-AKR, $250 \mu \mathrm{M}$ NADPH and $20 \mathrm{mM}$ substrate as indicated. None of the enzymes could reduce Darabinose, L-arabinose, glucose, mannose, ribose, tagatose, xylose, maltose, raffinose, sucrose, trehalose, and xylobiose 
sugar derivative 2,5-diketogluconate (Schweiger et al. 2010), which shows structural homologies to the newly discovered substrate 5-KF. Protein GOX1432 was previously described as mannitol dehydrogenase and reduced the sugars D-fructose and L-sorbose as well as the keto sugar 5-keto-D-gluconate (Table 3) (Zahid and Deppenmeier 2016).

As demonstrated above, $C$. pasteurianum was able to grow on 5-KF. Since the three proteins KFR from T. morbirosei, GOX0644 and GOX1432 from G. oxydans, were characterized as 5-KF reducing enzymes, Blastp analyses (https://blast. ncbi.nlm.nih.gov/Blast.cgi) were performed to identify corresponding enzymes in C. pasteurianum. Two proteins encoding a putative shikimate dehydrogenase (AJA49865.1) and a putative aldo/keto reductase (AJA48273.1) were similar to the KFR from T. morbirosei and protein GOX0644, respectively (similarities of $48 \%$ and $67 \%$ ). Both enzymes were produced in E. coli and purified via streptavidin affinity chromatography. While the putative shikimate dehydrogenase AJA49865.1 was inactive with 5-KF as substrate, high activity was detected for the aldo/keto reductase AJA48273.1 (referred to as CP-AKR). When analyzed by polyacrylamide gel electrophoresis and silver stain, a single band for CP-AKR could be detected that was in good accordance with the expected size of $35 \mathrm{kDa}$ (Fig. 5). Gel filtration analysis revealed that the native enzyme formed homotetramers. In addition, the kinetic parameters were investigated, indicating a $\mathrm{V}_{\max }$ value for $5-\mathrm{KF}$ of $48.9 \pm 7.1 \mathrm{U} \mathrm{mg}^{-1}$ and a low $\mathrm{K}_{\mathrm{M}}$ value of $1.3 \pm 0.2$ $\mathrm{mM}$. The $\mathrm{K}_{\mathrm{M}}$ for NADPH was $12.4 \pm 3.8 \mu \mathrm{M}$. The CP-AKR was able to reduce aldehydes as well as different ketones and, additionally, the reduction of 5-ketogluconate and L-sorboson could be shown (Table 3).

Although all described enzymes exhibited 5-KF reductase activity, significant differences were determined concerning the substrate spectrum, the corresponding amino acid sequence, and the tertiary and quaternary structure. To test whether also the reaction mechanism is different, an HPLC analysis of the end products of all four enzymes after 5-KF reduction was performed (Fig. 7). D-fructose and L-sorbose were applied as analytical standards (Fig. 7a). It became evident that protein GOX0644 and its homologous protein CPAKR produced L-sorbose as main product of 5-KF reduction (Fig. $7 \mathrm{c}$ and d). In contrast, protein GOX1432 and TM-KFR from T. morbirosei, which did not show sequence similarities, reduced 5-KF to D-fructose (Fig. $7 \mathrm{~b}$ and e). A closer look at the structure of 5-KF indicates that both prochiral keto groups are homotopic and have therefore the same chemical reactivity. Each $\mathrm{sp}^{2}$-hydridized trigonal planar carbonyl C-atom can be reduced by the enzymes from the re or the si face. Hence, the stereoselectivity of the 5-KF reducing enzymes with respect to the hydrid transfer from dehydronicotinamide to the substrate is responsible for the formation of $\mathrm{D}$-fructose or $\mathrm{L}$ sorbose.

\section{Involvement of the purified enzymes in the metabolism of 5-KF degrading bacteria}

C. pasteurianum was able to grow with 5-KF (Fig. 4). Furthermore, the aldo/keto reductase CP-AKR (AJA48273.1) from C. pasteurianum showed high 5-KF reducing activity. qRT-PCR experiments revealed that the mRNA abundance of the corresponding gene was increased about 10-fold during growth with 5-KF (Fig. 8), indicating that CP-AKR had an important function in the degradation of this substrate and might be responsible for the formation of fructose, which is then channelled into the central metabolism of $C$. pasteurianum. G. oxydans did not use 5-KF as substrate for growth. Therefore, it was not possible to test whether the proteins GOX0644 and GOX1432 were
Fig. 6 Analysis of

oxidoreductases from G. oxydans. Activity with known substrates (white columns), activity with 5KF (black columns). Assay consisted of $40 \mathrm{mM}$ potassium phosphate buffer $\mathrm{pH} 7,250 \mu \mathrm{M}$ $\mathrm{NADPH}, 5 \mathrm{mM}$ substrate and $2 \mu \mathrm{g}$ enzyme. The assays were incubated at $30^{\circ} \mathrm{C}$

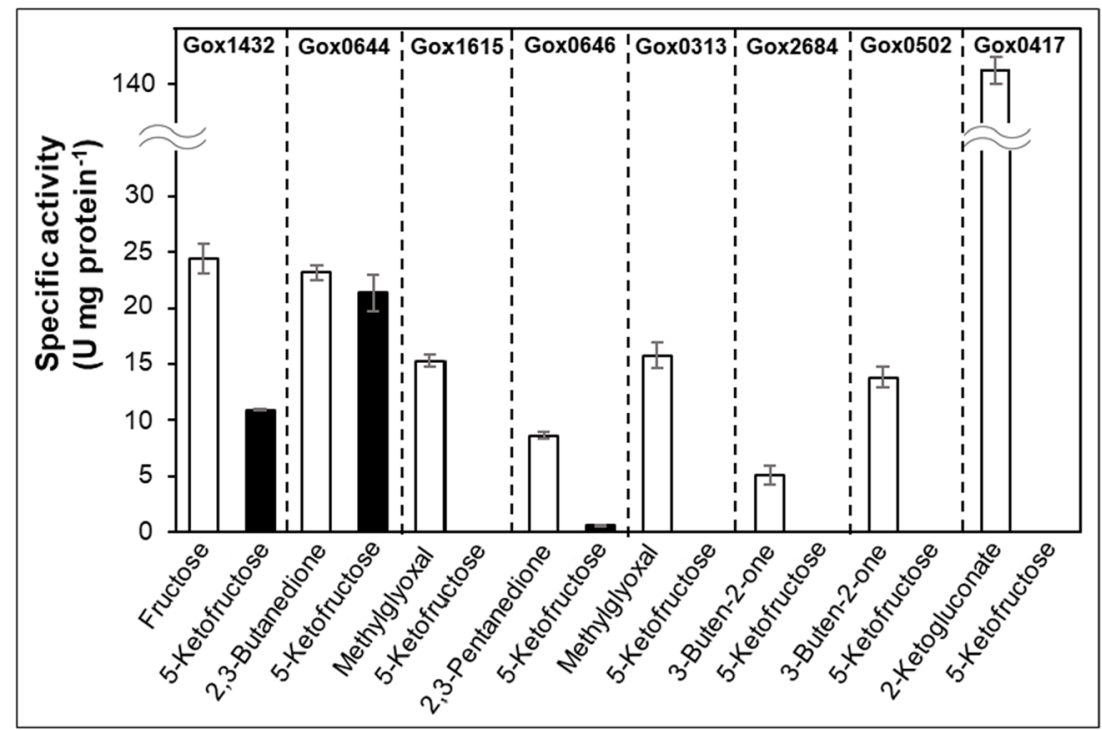




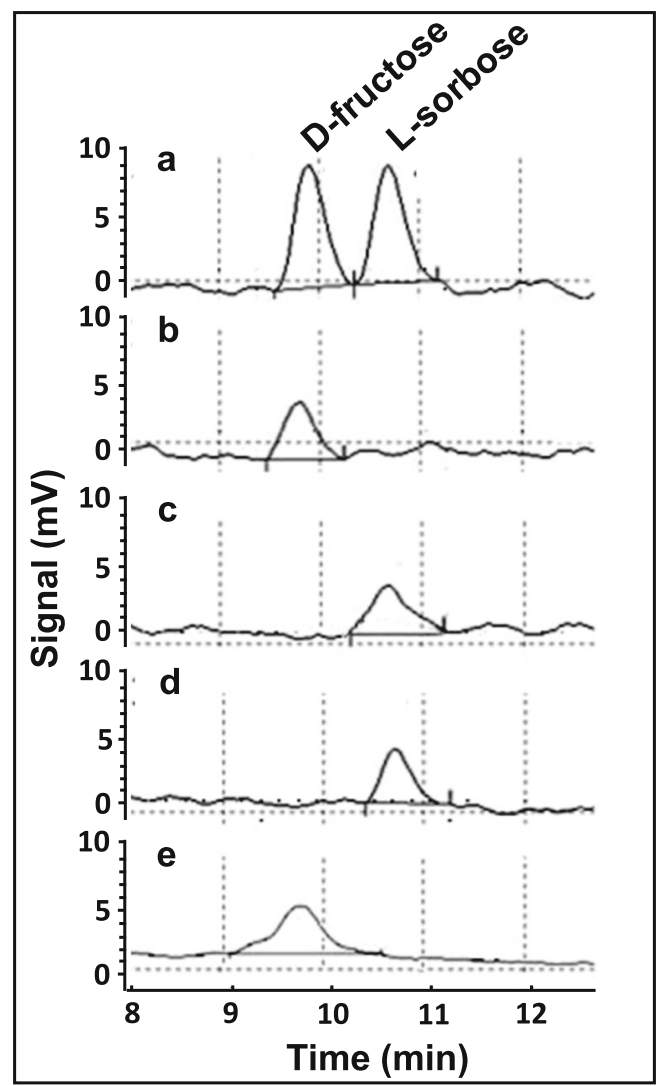

Fig. 7 Product analysis of 5-KF reduction. a D-fructose and L-sorbose standards. b Product of TM-KFR. c Product of protein GOX0644. d Product of CP-AKR. e Product of protein GOX1432. Enzyme assays contained $40 \mathrm{mM} \mathrm{KP}$ buffer $\mathrm{pH} 7$ or $\mathrm{pH} 6$ for CP-AKR, $5 \mathrm{mM}$ $\mathrm{NADPH}, 5 \mathrm{mM} 5-\mathrm{KF}$ and $2 \mu \mathrm{g}$ enzyme. The assays were incubated at $30{ }^{\circ} \mathrm{C}$ or at $40^{\circ} \mathrm{C}$ for CP-AKR for $3 \mathrm{~h}$. Reaction products were quantified by HPLC analysis via a UV detector

responsible for 5-KF reduction in vivo. However, in the 5-KF degrading bacterium G. japonicus LMG 26773, proteins with high similarity to the 5-KF reducing enzymes GOX0644 and GOX1432 were identified (Fig. S6). These enzymes were referred to as GJA0644 and GJA1432. The corresponding genes were analyzed by qRT-PCR and it was found that the mRNA concentrations were about 4-fold higher in 5-KF grown cells compared to cells, which used fructose as substrate (Fig. 8). The results indicate that the proteins GJA0644 and GJA1432 as counterparts of GOX0644 and GOX1432 are most probably involved in the first step of 5-KF degradation as performed by G. japonicus LMG 26773. In contrast to C. pasteurianum and G. japonicus LMG 26773, a change in the expression pattern of the gene encoding the 5-KF reductase TM-KFR was not observed in T. morbirosei (Fig. 8). However, for T. citrea, an almost identical 5-KF reductase has already been described and the enzyme was directly connected with the conversion of 5-KF into fructose as substrate for growth (Schrimsher et al. 1988).

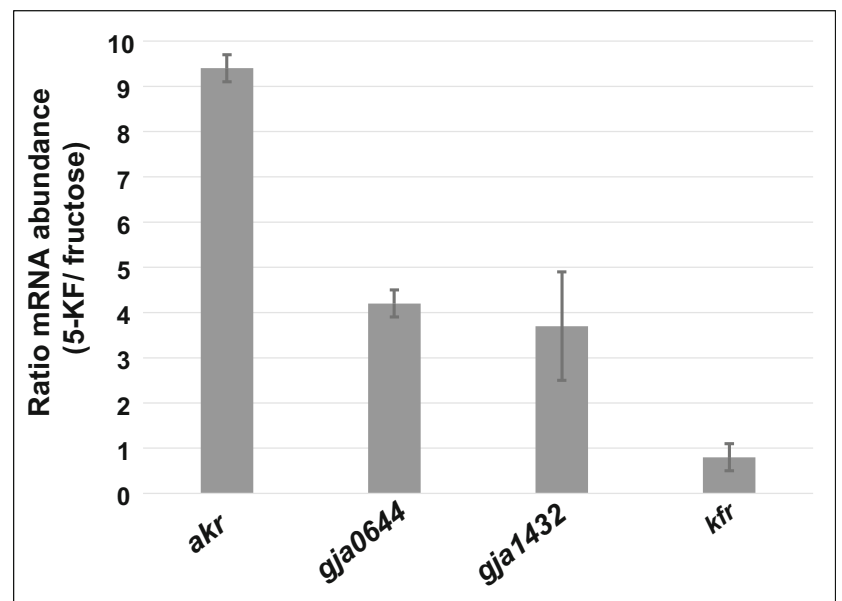

Fig. 8 Ratio of mRNA abundance of genes encoding 5-KF reducing enzymes. $\Delta \mathrm{Ct}$ values were calculated using the amount of ribosomal protein $\mathrm{L} 21$ transcripts as reference. Ratios were calculated from $\Delta \Delta \mathrm{Ct}$ values using the function $2^{-\Delta \Delta \mathrm{Ct}}$. Experiments were performed with RNA preparation from three different cultures harvested in the midexponential growth phase. Analyzed genes: $a k r$, gene CPAST_c38270 encoding the 5-KF reducing aldo/keto reductase CP-AKR (AJA49865.1) from C. pasteurianum DSM 525; gja0644, gene AD942_05425 encoding the 5-KF reducing enzyme GJA0644 (KXV40663.1) from G. japonicus LMG 26773; gja1432, gene AD942 03970 encoding the 5-KF reducing enzyme GJA1432 (KXV41067.1) from G. japonicus LMG 26773; kfr, gene HA49 09215 encoding the 5-KF reductase (KGD75378.1) from T. morbirosei DSM 23827

\section{Discussion}

In recent years, it has been demonstrated that conventional sugars such as sucrose, glucose, and fructose can promote the development of food-related diseases (Malik et al. 2010; Schulze 2004; Ludwig et al. 2001; Malik et al. 2006; Johnson et al. 2007) such as type 2 diabetes, obesity, and cardiovascular diseases. It can also be observed that consumers are increasingly paying attention to a more conscious diet leading to an increased demand for calorie-free or lowcalorie substitutes as an alternative to traditional sweeteners (Marti et al. 2008; Ogden et al. 2006). A promising alternative to natural sugars and artificial sweeteners is the bacterially produced fructose derivative $5-\mathrm{KF}$. Tests with trained taste specialists have shown that the sweetening power and taste are equivalent to the properties of pure fructose. Thus, 5-KF has a stronger sweetening power than sucrose (Herweg et al. 2018; Stone and Oliver 1969). The compound revealed a similar intrinsic sweet threshold concentration in comparison to fructose. Moreover, there is no artificial, bitter or licorice-like aftertaste, which is noticeable when using some other alternative sweeteners such as stevia, saccharin, and acesulfame K (Soejarto et al. 1982; Herweg et al. 2018; Kuhn et al. 2004). In addition, 5-KF is a natural sugar derivative that is found, e.g., in honey, white wine, and vinegar (Siemen et al. 2018), leading to the question of how 5-KF is degraded in nature. 
The analysis of hexose interconversion in Erwinia species showed that Erwinia citreus (now referred to as T. citrea) can use 5-KF, and possesses a NADPH-dependent reductase, which catalyzes the reduction of 5-KF to fructose (Schrimsher et al. 1988). Here we show that T. morbirosei possesses a very similar enzyme and can grow with 5-KF as carbon and energy source. In nature, 5-KF is produced by Gluconobacter species through oxidation of fructose by the membrane-bound enzyme Fdh (Ameyama et al. 1981; Kawai et al. 2013; Yamada et al. 1966; Siemen et al. 2018). The partial oxidation of sugars and polyols is a typical process for Gluconobacter species and is referred to as incomplete oxidation (Matsushita et al. 1994). Several sugars and polyols are attacked in this way. The partly oxidized products (e.g., ketogluconates from glucose and L-sorbose from D-sorbitol) are taken up by the cells and are consumed in the second growth phase or allow survival in the stationary phase (Matsushita et al. 1994). To channel the partially oxidized products into the central carbon metabolism, the organisms contain a repertoire of cytoplasmic oxidoreductases that reduce the products, which are then phosphorylated and degraded in the pentose phosphate pathway (Matsushita et al. 1994). The question was whether such a cytoplasmic oxidoreductase also exists for the reduction of 5-KF to fructose, which can be metabolized to gain ATP and intermediates for biosynthesis. Our growth experiments indicated that Gluconobacter species, which produce 5-KF naturally, were indeed able to utilize the sugar derivative as a carbon and energy source (Fig. 2).

Tatumella and Gluconobacter species are microorganisms thriving in aerobic habitats where 5-KF is commonly present due to the fructose dehydrogenase activity of certain Gluconobacter spp. Interestingly, we also found that the strictly fermentative anaerobe $C$. pasteurianum can grow with 5$\mathrm{KF}$ as well, though other members of the order Clostridiales (e.g. Clostridium leptum and Agathobacterobacter rectalis) were not able to utilize this compound (Fig. S5). C. pasteurianum mainly uses mono- and polysaccharides as substrates, which are metabolized by glycolysis and converted to butyrate, acetate, and ethanol by butyrate fermentation. Although the organism does not share the same habitats as the strictly oxygen-dependent 5 -KF producing Gluconobacter spp., it is not unlikely that $C$. pasteurianum is exposed to higher concentrations of 5-KF in nature. As an organism that was isolated from carrot slices and spoiled fruit juices (Dworkin and Gutnick 2012; Feng et al. 2010) C. pasteurianum is able to thrive in rotting fruit and vegetable matter, which presumably could have accumulated 5-KF beforehand due to the activity of Gluconobacter spp. Hence, it is tempting to speculate that the ability to metabolize $5-\mathrm{KF}$ is not limited to 5-KF producing species but could also be found in bacteria that come in contact with this compound in their natural habitats.
In this context, it is important to understand whether the dietary consumption of 5-KF could also influence the human gut microbiota. As stated above, $5-\mathrm{KF}$ is a potential candidate as an additive in food production for the reduction of highcalorie sugars in processed foods. It is therefore essential to investigate the influence of this compound on the human intestinal flora. The balance in the intestinal flora, which is closely linked to human health, can be shifted by diet. If microorganisms are able to metabolize 5-KF, unlike other representatives of the intestinal microbiota, they will be enriched while the latter group is suppressed. This may affect human well-being and digestion (Autenrieth 2017; Suez et al. 2014). We were able to show that representative microorganisms of the human intestinal tract could not grow on 5-KF as the sole carbon source. Because the selected microorganisms represented the most common and abundant genera in the human intestines, it is unlikely that metabolization of 5-KF occurs within the human gut in considerable amounts. Moreover, since there was also no production of fermentation endproducts deriving from 5-KF like, e.g., the short-chain fatty acids propionate, acetate, or butyrate that could contribute to the nutritional value of the sugar derivative (Scheppach 1994), 5-KF can presumably be considered a calorie-free sugar substitute for human dietary applications.

Though we did not find any 5-KF reduction activity in the selected members of gut bacteria, the organisms we found capable of this catalysis were nevertheless phylogenetically rather distant. Unsurprisingly, this also led to the discovery of different enzymes that were responsible for the turnover of 5-KF. Altogether, we were able to identify four enzymes capable of 5-KF reduction that belong to three unrelated enzymatic classes with very different amino acid sequences and structural properties. The first one, TM-KFR from T. morbirosei, showed high similarities $(94 \%)$ to the $5-\mathrm{KF}$ reductase from $T$. citrea, which in turn is related to shikimate dehydrogenases (EC 1.1.1.25) (Schrimsher et al. 1988). In contrast, the second and third enzyme, GOX0644 from G. oxydans and CP-AKR from C. pasteurianum, belong to the aldo-keto reductase (AKR) superfamily, which show highest similarity to the 2,5-diketo-D-gluconate dehydrogenases from E. coli (70\%) and Corynebacterium sp. (65\%) together with the glyoxal reductase from Bacillus subtilis (69\%). Lastly, protein GOX1432 from G. oxydans was previously described as a mannitol dehydrogenase (EC 1.1.1.138). The enzyme is responsible for mannitol-mediated osmoprotection in these organisms and reduces D-fructose to D-mannitol under physiological conditions (Zahid and Deppenmeier 2016). Furthermore, it has the ability to reduce L-sorbose to D-sorbitol and 5-ketogluconate to gluconate (Zahid and Deppenmeier 2016). Thus, protein GOX1432 shows a totally different substrate spectrum than described for KFR from T. morbirosei and T. citrea. As a basic principle, 5 -KF reduction creates either L-sorbose or D-fructose 
depending on the stereoselectivity of the enzymes (Fig. 7). Our hypothesis is that the reduction of the si face of the planar C-carbonyl structure by the enzymes TM-KFR and GOX1432 leads to the formation of D-fructose. In the other case, the keto group is reduced at the $r$ face by the $5-\mathrm{KF}$ reducing enzymes GOX0644 and CP-AKR resulting in the production of Lsorbose.

Supplementary Information The online version contains supplementary material available at https://doi.org/10.1007/s00253-021-11168-3.

Acknowledgements The authors thank Marcel Hövels (Institute of Microbiology and Biotechnology, University of Bonn, Germany) for HPLC support and Dr. Julia Lofi (Institute of Microbiology and Biotechnology, University of Bonn, Germany) for the help with gel filtration chromatography. We also thank Natalie Thum-Schmitz (Institute of Microbiology and Biotechnology, University of Bonn, Germany) for technical assistance and Prof. Sigurd Höger (Institute of Organic Chemistry, University of Bonn, Germany) for support to analyze the stereospecificity of the 5-KF reducing enzymes.

Author contribution UD designed the study and wrote the paper. JS designed and performed most the experiments. JJH, LSG, and JH conducted same experiments. KK designed and performed experiments and contributed with TF to the study's conception, data analysis, and interpretation of the results. All authors analyzed the results and approved the final version of the manuscript.

Funding The study was supported by funding of the BMBF project IMPRES (FKZ 031B0370A). The funding agency was not involved in the research.

Data availability Data are available upon request from the authors.

Code availability Not applicable.

\section{Declarations}

Ethics approval This article does not contain any studies with human participants or animals performed by any of the authors.

Consent to participate Not applicable.

Consent for publication Not applicable.

Conflict of interest The authors declare that they have no conflict of interest.

Open Access This article is licensed under a Creative Commons Attribution 4.0 International License, which permits use, sharing, adaptation, distribution and reproduction in any medium or format, as long as you give appropriate credit to the original author(s) and the source, provide a link to the Creative Commons licence, and indicate if changes were made. The images or other third party material in this article are included in the article's Creative Commons licence, unless indicated otherwise in a credit line to the material. If material is not included in the article's Creative Commons licence and your intended use is not permitted by statutory regulation or exceeds the permitted use, you will need to obtain permission directly from the copyright holder. To view a copy of this licence, visit http://creativecommons.org/licenses/by/4.0/.

\section{References}

Ameyama M, Shinagawa E, Matsushita K, Adachi O (1981) D-fructose dehydrogenase of Gluconobacter industrius: purification, characterization, and application to enzymatic microdetermination of D-fructose. J Bacteriol 2:814-823. https://doi.org/10.1128/JB.145.2.814823.1981

Autenrieth IB (2017) The microbiome in health and disease: a new role of microbes in molecular medicine. J Mol Med 1:1-3. https://doi.org/ 10.1007/s00109-016-1499-8

Blasi M, Barbe J-C, Dubourdieu D, Deleuze H (2008) New method for reducing the binding power of sweet white wines. J Agric Food Chem 18:8470-8474. https://doi.org/10.1021/j1800665e

Blum H, Beier H, Gross HJ (1987) Improved silver staining of plant proteins, RNA and DNA in polyacrylamide gels. Electrophoresis 2:93-99. https://doi.org/10.1002/elps.1150080203

Burroughs LF, Sparks AH (1973) Sulphite-binding power of wines and ciders. 3. Determination of carbonyl compounds in a wine and calculation of its sulphite-binding power. J Sci Food Agric 2:207-217. https://doi.org/10.1002/jsfa.2740240213

Dowell VR, Hawkins TM (1974) Laboratory methods in anaerobic bacteriology, CDC Laboratory Manual. CDC Information Center, Georgia

Dworkin M, Gutnick D (2012) Sergei Winogradsky: a founder of modern microbiology and the first microbial ecologist. FEMS Microbiol Rev 2:364-379. https://doi.org/10.1111/j.1574-6976.2011.00299.x

Feng G, Churey JJ, Worobo RW (2010) Thermoaciduric Clostridium pasteurianum spoilage of shelf-stable apple juice. J Food Prot 10: 1886-1890. https://doi.org/10.4315/0362-028x-73.10.1886

Grembecka M (2015) Sugar alcohols - their role in the modern world of sweeteners: a review. Eur Food Res Technol 241:1-14. https://doi. org/10.1007/s00217-015-2458-2

Herweg E, Schöpping M, Rohr K, Siemen A, Frank O, Hofmann T, Deppenmeier U, Büchs J (2018) Production of the potential sweetener 5-ketofructose from fructose in fed-batch cultivation with Gluconobacter oxydans. Bioresour Technol 259:164-172. https:// doi.org/10.1016/j.biortech.2018.03.038

Hoffmann JJ, Hövels M, Kosciow K, Deppenmeier U (2020) Synthesis of the alternative sweetener 5-ketofructose from sucrose by fructose dehydrogenase and invertase producing Gluconobacter strains. J Biotechnol 307:164-174. https://doi.org/10.1016/j.jbiotec.2019.11.001

Johnson RJ, Segal MS, Sautin Y, Nakagawa T, Feig DI, Kang D-H, Gersch MS, Benner S, Sánchez-Lozada LG (2007) Potential role of sugar (fructose) in the epidemic of hypertension, obesity and the metabolic syndrome, diabetes, kidney disease, and cardiovascular disease. Am J Clin Nutr 4:899-906. https://doi.org/10.1093/ajcn/ 86.4.899

Johnson M, Zaretskaya I, Raytselis Y, Merezhuk Y, McGinnis S, Madden TL (2008) NCBI BLAST: a better web interface. Nucleic Acids Res 36(Web Server issue):W5-W9. https://doi.org/10.1093/ nar/gkn201

Kawai S, Goda-Tsutsumi M, Yakushi T, Kano K, Matsushita K (2013) Heterologous overexpression and characterization of a flavoproteincytochrome c complex fructose dehydrogenase of Gluconobacter japonicus NBRC3260. Appl Environ Microbiol 5:1654-1660. https://doi.org/10.1128/AEM.03152-12

Kosciow K, Domin C, Schweiger P, Deppenmeier U (2016) Extracellular targeting of an active endoxylanase by a TolB negative mutant of Gluconobacter oxydans. J Ind Microbiol Biotechnol 7:989-999. https://doi.org/10.1007/s10295-016-1770-6

Kröninger L, Gottschling J, Deppenmeier U (2017) Growth characteristics of Methanomassiliicoccus luminyensis and expression of methyltransferase encoding genes. Archaea 2017:2756573-2756512. https://doi.org/10.1155/2017/2756573. eCollection 2017 
Kuhn C, Bufe B, Winnig M, Hofmann T, Frank O, Behrens M, Lewtschenko T, Slack JP, Ward CD, Meyerhof W (2004) Bitter taste receptors for saccharin and acesulfame K. J Neurosci 45: 10260-10265. https://doi.org/10.1523/JNEUROSCI.1225-04.2004

Laemmli UK (1970) Cleavage of structural proteins during the assembly of the head of bacteriophage T4. Nature 5259:680-685. https://doi. org $/ 10.1038 / 227680 \mathrm{a} 0$

Ludwig DS, Peterson KE, Gortmaker SL (2001) Relation between consumption of sugar-sweetened drinks and childhood obesity: a prospective, observational analysis. The Lancet 9255:505-508. https:// doi.org/10.1016/S0140-6736(00)04041-1

Malik VS, Schulze MB, Hu FB (2006) Intake of sugar-sweetened beverages and weight gain: a systematic review. Am J Clin Nutr 2:274 288. https://doi.org/10.1093/ajcn/84.1.274

Malik VS, Popkin BM, Bray GA, Després J-P, Hu FB (2010) Sugarsweetened beverages, obesity, type 2 diabetes mellitus, and cardiovascular disease Risk. Circulation 11:1356-1364. https://doi.org/10. 1161/CIRCULATIONAHA.109.876185

Marti N, Funes LL, Saura D, Micol V (2008) An update on alternative sweeteners. Agro Food Industry Hi-Tech 19:8-10

Matsushita K, Toyama H, Adachi O (1994) Respiratory chains and bioenergetics of acetic acid bacteria. Adv Microb Physiol 36:247-301. https://doi.org/10.1016/S0065-2911(08)60181-2

Mattes RD, Popkin BM (2009) Nonnutritive sweetener consumption in humans: effects on appetite and food intake and their putative mechanisms. Am J Clin Nutr 1:1-14. https://doi.org/10.3945/ajen.2008. 26792

McIlvaine TC (1921) A buffer solution for colorimetric comparison. J Biol Chem 1:183-186

Miller JH (1972) Experiments in molecular genetics. Cold Spring Harbor Laboratory Press, New York

Ogden CL, Carroll MD, Curtin LR, McDowell MA, Tabak CJ, Flegal KM (2006) Prevalence of overweight and obesity in the united states, 1999-2004. JAMA 13:1549-1555. https://doi.org/10.1001/ jama.295.13.1549

Rauch B, Pahlke J, Schweiger P, Deppenmeier U (2010) Characterization of enzymes involved in the central metabolism of Gluconobacter oxydans. Appl Microbiol Biotechnol 3:711-718. https://doi.org/10. 1007/s00253-010-2779-9

Scheppach W (1994) Effects of short chain fatty acids on gut morphology and function. Gut 1:35-38. https://doi.org/10.1136/gut.35.1 suppl.s35

Schiffman SS, Reilly DA, Clark TB (1979) Qualitative differences among sweeteners. Physiol Behav 1:1-9. https://doi.org/10.1016/ 0031-9384(79)90113-6

Schrimsher JL, Wingfield PT, Bernard A, Mattaliano R, Payton MA (1988) Purification and characterization of 5-ketofructose reductase from Erwinia citreus. Biochem J 2:511-516. https://doi.org/10. $1042 / b j 2530511$

Schulze MB (2004) Sugar-sweetened beverages, weight gain, and incidence of type 2 diabetes in young and middle-aged women. JAMA 8:927-934. https://doi.org/10.1001/jama.292.8.927
Schweiger P, Gross H, Wesener S, Deppenmeier U (2008) Vinyl ketone reduction by three distinct Gluconobacter oxydans $621 \mathrm{H}$ enzymes. Appl Microbiol Biotechnol 6:995-1006. https://doi.org/10.1007/ s00253-008-1600-5

Schweiger P, Gross H, Deppenmeier U (2010) Characterization of two aldo-keto reductases from Gluconobacter oxydans $621 \mathrm{H}$ capable of regio- and stereoselective alpha-ketocarbonyl reduction. Appl Microbiol Biotechnol 4:1415-1426. https://doi.org/10.1007/ s00253-010-2607-2

Schweiger P, Gross H, Zeiser J, Deppenmeier U (2013) Asymmetric reduction of diketones by two Gluconobacter oxydans oxidoreductases. Appl Microbiol Biotechnol 8:3475-3484. https://doi.org/10. 1007/s00253-012-4395-3

Siemen A, Kosciow K, Schweiger P, Deppenmeier U (2018) Production of 5-ketofructose from fructose or sucrose using genetically modified Gluconobacter oxydans strains. Appl Microbiol Biotechnol 4: 1699-1710. https://doi.org/10.1007/s00253-017-8699-1

Soejarto DD, Kinghorn AD, Farnsworth NR (1982) Potential sweetening agents of plant origin. III. Organoleptic evaluation of Stevia leaf herbarium samples for sweetness. J Nat Prod 5:590-599. https:// doi.org/10.1021/np50023a013

Stone H, Oliver SM (1969) Measurement of the relative sweetness of selected sweeteners and sweetener mixtures. J Food Science 2: 215-222. https://doi.org/10.1111/j.1365-2621.1969.tb00922.x

Suez J, Korem T, Zeevi D, Zilberman-Schapira G, Thaiss CA, Maza O, Israeli D, Zmora N, Gilad S, Weinberger A, Kuperman Y, Harmelin A, Kolodkin-Gal I, Shapiro H, Halpern Z, Segal E, Elinav E (2014) Artificial sweeteners induce glucose intolerance by altering the gut microbiota. Nature 7521:181-186. https://doi.org/10.1038/ nature 13793

Varel VH, Bryant MP (1974) Nutritional features of Bacteroides fragilis subsp. fragilis. Appl Microbiol 2:251-257. https://doi.org/10.1128/ aem.28.2.251-257.1974

Vastenavond C, Bertelsen H, Hansen S, Laursen R, Saunders J, Eriknauer K (2011) Alternative sweeteners. CRC Press, Florida

Wiet SG, Beyts PK (1992) Sensory characteristics of sucralose and other high intensity sweeteners. J Food Sci 4:1014-1019. https://doi.org/ 10.1111/j.1365-2621.1992.tb14345.x

Wyrobnik DH, Wyrobnik IH, Silcoff ER (2009) Agent for use in the case of fructose intolerance US 2009/0081300 A1

Yamada Y, Aida K, Uemura T (1966) A New Enzyme, D-Fructose Dehydrogenase. Agric Biol Chem 1:95-96. https://doi.org/10. 1271/bbb1961.30.95

Zahid N, Deppenmeier U (2016) Role of mannitol dehydrogenases in osmoprotection of Gluconobacter oxydans. Appl Microbiol Biotechnol 23:9967-9978. https://doi.org/10.1007/s00253-0167680-8

Publisher's note Springer Nature remains neutral with regard to jurisdictional claims in published maps and institutional affiliations. 